\title{
$\mathrm{R}^{\text {juknal }}$ ETSVINDING
}

\section{Peran Serta Masyarakat dan Dunia Usaha Dalam Mewujudkan Sistem Transparansi Nasional Pelayanan Publik}

(Public and Business Participation in Building National Public Service Transparancy System)

Tirta N. Mursitama, Ph.D

Dosen Departemen Hubungan Internasional Fakultas Humaniora Universitas Bina Nusantara

\begin{abstract}
Abstrak
Pelayanan publik merupakan pilar penting reformasi birokrasi yang menjadi tolok ukur kinerja pemerintah. Namun, lebih dari sepuluh tahun reformasi bergulir dan implementasi otonomi daerah, fakta memperlihatkan masih minimnya perubahan substansial dalam penyelenggaraan pelayanan publik di Indonesia. Permasalahan yang diangkat dalam tulisan ini adalah bagaimana keterkaitan organisasi masyarakat, dunia usaha dan layanan publik; serta bagaimana peran organisasi masyarakat dan dunia usaha dalam mendorong terwujudnya transparansi pelayanan publik. Dengan menggunakan pendekatan yuridis empiris, tulisan ini menyimpulkan bahwa dalam pelayanan publik, terdapat 3 (tiga) aktor yang terlibat, yaitu: masyarakat, dunia usaha, dan pemerintah yang dimotori oleh birokrasi. Ketiganya tidak bisa berdiri sendiri melainkan saling berkaitan dan mendukung perwujudan sistem transparansi nasional. Untuk itu perlu dibangun strategi kerjasama segitiga antara pemerintah, masyarakat dan dunia usaha dalam rangka mewujudkan birokrasi yang professional, efisien, cepat, dan bekerja berdasarkan prinsip-prinsip tata kelola yang baik.
\end{abstract}

Kata Kunci: masyarakat madani, dunia usaha, transparansi, pelayanan publik, pemerintah, birokrasi, administrasi, korupsi

\section{Abstract}

Public service is one of the important pillars of bureucracy reform which serves as a benchmark of government performance. However, after more than a decade of reform and the implementation of local autonomy, it shows a limited progress of public service in Indonesia. This article attempts to address two questions: 1) How are the interlinkages between civil society and business in public service? 2) What is the role of civil society and business in promoting public service transparancy? By utilising empirical approach, this article concludes that there are three key actors involved in public services namely society, business, and government which are heavily interrelated and supportive in promoting national public service transparancy system. Hence, we need to develop a strategy of triangular cooperation among government, community and business in order to create a professional and efficient bureaucracy on the basis of good governance principles.

Keywords: civil society, business, transparancy, public service, government, bureaucracy, administration, corruption 


\section{A. Pendahuluan ${ }^{1}$}

Pelayanan publik merupakan pilar penting reformasi birokrasi yang menjadi tolok ukur kinerja pemerintah. Namun, lebih dari sepuluh tahun reformasi bergulir dan implementasi otonomi daerah, fakta memperlihatkan masih minimnya perubahan substansial dalam penyelenggaraan pelayanan publik di negeri ini.

Indeks integritas pelayanan publik pada tahun 2010 pun menujukkan penurunan dibanding tahun-tahun sebelumnya. Beberapa instansi maupun daerah memang menunjukkan peningkatan kualitas pelayanan pelayanan publik, namun secara umum kualitas pelayanan publik masih sangat kurang bahkan cenderung bobrok.

Tulisan ini bertujuan membahas peran organisasi masyarakat sebagai bagian dari masyarakat madani (civil society) dan dunia usaha dalam mendorong terwujudnya sistem transparansi nasional pelayanan publik. Argumentasi yang dikedepankan adalah kerjasama antara pemerintah, swasta dan masyarakat dalam mewujudkan sistem transparansi nasional pelayanan publik merupakan sebuah keharusan.

Tulisan ini terbagi dalam tiga bagian utama. Pertama, upaya pendefinisian organisasi masyarakat, dunia usaha dan layanan publik serta keterkaitan antara ketiganya. Bagian kedua memaparkan kerangka kerja untuk menganalisa peran organisasi masyarakat. Sedangkan bagian ketiga berupa penutup.

\section{B. Permasalahan}

Dari uraian di atas, dapat dirumuskan permasalahan sebagai berikut:

1. Bagaimana keterkaitan organisasi masyarakat, dunia usaha dan layanan publik?

2. Bagaimana kondisi pelayanan publik saat ini?

3. Bagaimana peran organisasi masyarakat dan dunia usaha dalam mendorong terwujudnya transparansi pelayanan publik?

\section{Metode Penelitian}

Berdasarkan permasalahan dan tujuan penelitian di atas, penelitian ini dilakukan dengan menggunakan pendekatan empiris², yaitu pendekatan yang digunakan untuk melihat gejala-gejala sosial yang berkaitan dengan hukum di tengah masyarakat.

1 Tulisan ini diolah kembali dari makalah yang penulis dipresentasikan dalam Seminar Nasional Sistem Transparansi Nasional Pelayanan Publik yang diselenggarakan oleh Badan Pembinaan Hukum Nasional (BPHN) Kementerian Hukum dan Has Asasi Manusia Republik Indonesia di Yogyakarta, 15 Maret 2011.

Penelitian empiris adalah penelitian yang dilakukan dengan cara meneliti data-data primer, yaitu data yang diperoleh langsung dari masyarakat. Pemikiran empiris ini disebut juga pemikiran sosiologis. Lebih jauh tentang ini lihat Soerjono Soekanto dan Sri Mamudji, Penelitian Hukum Normatif: Suatu Tinjauan Singkat, (Jakarta: CV. Rajawali, 2011), hal. 14-15. 
D. Pembahasan

\section{Korelasi Organisasi Masyarakat, Dunia Usaha dan Layanan Publik}

\section{a. Organisasi Masyarakat}

Organisasi masyarakat diartikan sebagai organisasi-organisasi masyarakat madani, civil society organizations (CSOs). Dalam batasan ini yang termasuk di dalamnya adalah organisasi keagamaan, organisasi berbasis massa, perserikatan, organisasi berbasis etnik, organisasi komunitas, organisasi non-pemerintah, asosiasi profesional dan organisasi yang memiliki afiliasi politik. ${ }^{3}$ Untuk kepentingan pembahasan dalam tulisan ini organisasi dan atau jaringan yang disebut di atas diposisikan di luar aparat negara yang formal.

\section{b. Dunia Usaha}

Dunia usaha secara sederhana diartikan sebagai kalangan pengusaha / entrepreneur baik dalam konteks individual maupun gabungan dalam asosiasi pengusaha.

\section{c. Layanan Publik}

$$
\text { Undang-Undang Nomor } 25
$$

Tahun 2009 tentang Pelayanan Publik menyebutkan bahwa pelayanan publik adalah kegiatan atau rangkaian kegiatan dalam rangka pemenuhan kebutuhan pelayanan sesuai dengan peraturan perundang-undangan bagi setiap warga negara dan penduduk atas barang, jasa, dan/atau pelayanan administratif yang disediakan oleh penyelenggara pelayanan publik. Menurut Pasal 4 undang-undang ini, penyelenggaraan pelayanan publik berasaskan:kepentinganumum, kepastian hukum, kesamaan hak, keseimbangan hak dan kewajiban, keprofesionalan, partisipatif, persamaan perlakuan / tidak diskriminatif, keterbukaan, akuntabilitas, fasilitas dan perlakuan khusus bagi kelompok, rentan, ketepatan waktu, serta kecepatan, kemudahan, dan keterjangkauan.

Birokrasi merupakan aktor utama dalam penyediaan pelayanan publik. Birokrasi pada prinsipnya merupakan gabungan fungsi dari berbagai faktor dalam kerangka penyelenggaraan pemerintahan. Sebagai mesin negara, birokrasi memiliki legitimasi tunggal untuk menghadirkan pelayanan prima kepada publik. Adapun faktor-faktor utama yang mempengaruhi pelayanan publik dan penyelenggaraan pemerintahan di Indonesia antara lain adalah kelembagaan, kepegawaian, proses pengawasan, dan

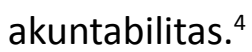

Hans Antlov, Rustam Ibrahim dan Peter van Tuij, “NGO Governance and Accountability in Indonesia: Challenges in a Newly Democratizing Country" dalam Lisa Jordan dan Peter van Tuij (eds), "NGO Accountability: Politics, Principles and Innovations", (London: Earthscan, 2006), hal. 146.

4 Eko Prasodjo, Reformasi Kedua, (Jakarta: Salemba Humanika, 2009) hal. 80. 
Faktor-faktor tersebut merupakan penentu baik-buruknya proses pelayanan yang diberikan. Namun, faktanya saat ini memperlihatkan bahwa faktor-faktor tersebut belum mampu disinergikan, bahkan ada kecenderungan terdapat faktor yang hilang.

\section{Kondisi Terkini Pelayanan Publik}

Komisi Pemberantasan Korupsi (KPK) secara reguler menyelenggarakan survei integritas pelayanan publik baik di pusat maupun di daerah sejak tahun 2007. Grafik 1 di bawah ini menggambarkan bahwa integritas pelayanan publik meningkat dari tahun 2007 ke tahun 2008. Namun sejak tahun 2008, integritas pelayanan publik baik di pusat maupun di daerah terus mengalami penurunan.

Pada tahun 2008, indeks pelayanan publik di tingkat pusat adalah 6,84 kemudian menurun menjadi 6,64 pada tahun 2009. Pada tahun 2010 kembali mengalami penurunan ke angka 6,16. Walau masih di atas angka 6 yang merupakan standar minimal pelayanan publik yang dianggap memadai.

Kondisi demikian dapat digambarkan secara lebih detail dengan gambar Grafik 1.

Sedangkan untuk indeks integritas pelayanan publik di tingkat daerah pun setali tiga uang alias sama saja. Penurunan juga terjadi sejak tahun 2008 dari 6,69 menjadi 6,46 pada tahun 2009 dan semakin memburuk di tahun 2010 menjadi 5,07. Dari hasil survei tersebut menunjukkan bahwa integritas pelayanan publik terus memburuk. Ini menandakan ada permasalahan dalam pelayanan publik. Bahkan untuk pelayanan publik di daerah di bawah standar minimum yang ditetapkan KPK.

Dalam tabel 1 disajikan hasil survei integritas pelayanan publik tahun 2010 yang memiliki skor nilai di atas 6 . Unit layanan di bawah ini dikategorikan memiliki integritas pelayanan yang baik. Para pemakai jasa merasa puas dengan pelayanan yang mereka dapatkan. Salah satu contohnya, adalah izin

Grafik 1 Integritas Pelayanan Publik 2007-2010

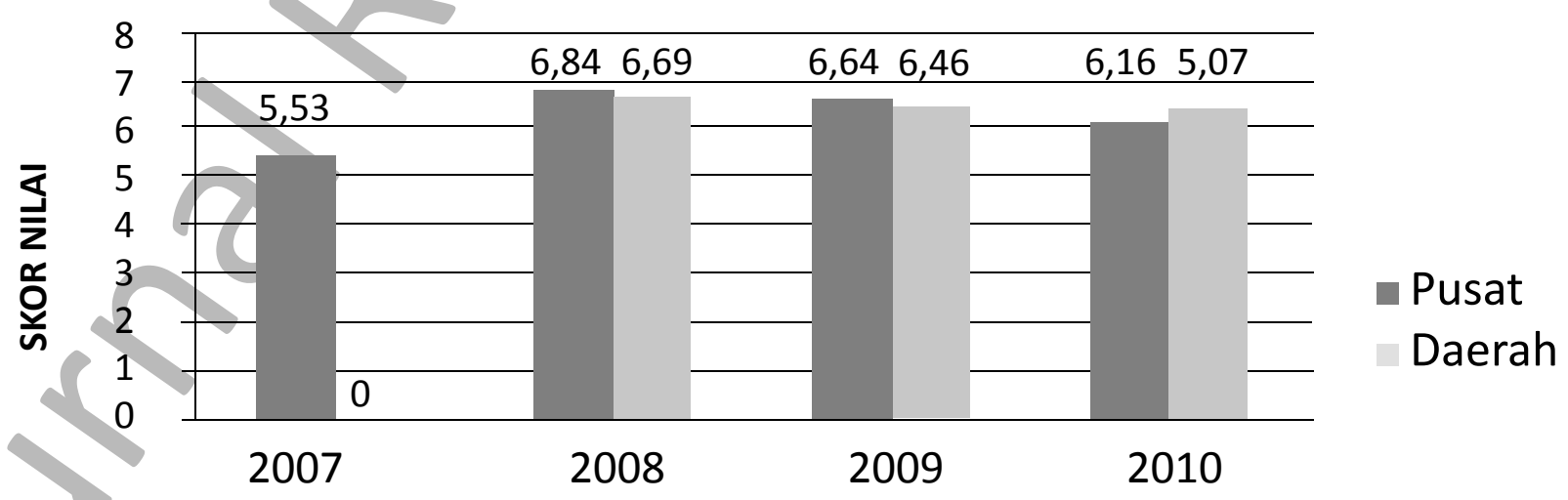

Tahun 
Tabel 1 Unit Layanan yang Memiliki Indeks Di atas 6

\begin{tabular}{|c|c|c|}
\hline No. & Unit Layanan & $\begin{array}{l}\text { Indeks } \\
\text { Integritas }\end{array}$ \\
\hline 1 & Izin pemasukan dan pengeluaran benih - Kementerian Pertanian & 7,7 \\
\hline 2 & Izin Usaha Tetap - Badan Koordinasi Penanaman Modal & 7,67 \\
\hline 3 & Izin pemasukan karkas, jeroan dan daging dari luar negeri - Kementerian Pertanian & 7,56 \\
\hline 4 & Pengajuan Tanda Pendaftaran Tipe Kendaraan Bermotor (TPT) - Kementerian Perindustrian & 7,56 \\
\hline 5 & Penerbitan Angka Pengenal Importir Terbatas (APIT) - Badan Koordinasi Penanaman Modal & 7,5 \\
\hline 6 & Pendaftaran MD/ML - Badan Pengawas Obat dan Makanan & 7,48 \\
\hline 7 & Sewa Lahan - PT. Kawasan Berikat Nusantara & 7,45 \\
\hline 8 & Layanan Kas ke Bank Umum - Bank Indonesia & 7,37 \\
\hline 9 & Izin prinsip dan izin usaha BPR - Bank Indonesia & 7,34 \\
\hline 10 & Jasa Pelayanan Logistik - PT. Kawasan Berikat Nusantara & 7,17 \\
\hline 11 & Layanan legislasi bagi dokumen yang akan digunakan di luar negeri - Kementerian Luar Negeri & 7,14 \\
\hline 12 & $\begin{array}{l}\text { Perizinan Ekspor/Impor terhadap barang-barang yang termasuk kategori makanan dan obat- } \\
\text { obatan - Badan Pengawas Obat dan Makanan }\end{array}$ & 7,13 \\
\hline 13 & Sertifikasi Peralatan - Kementerian Komunikasi dan Informatika & 7,13 \\
\hline 14 & Sertifikasi Produk - PT. Sucofindo & 7,07 \\
\hline 15 & Izin prinsip dan izin tetap industri obat tradisional - Kementerian Kesehatan & 7,06 \\
\hline 16 & Izin Pengangkutan BBM - Kementerian Energi dan SDM & 7,06 \\
\hline 17 & Layanan Kepengurusan Paspor Dinas - Kementerian Luar Negeri & 7,05 \\
\hline 18 & Sertifikasi ISO - PT. Sucofindo & 7,03 \\
\hline 19 & Izin Usaha Industri Primer Hasil Hutan Kayu (UIPHHK) - Kementerian Kehutanan & 6,99 \\
\hline 20 & $\begin{array}{l}\text { Izin Pemungutan Hasil Hutan Kayu dan bukan kayu pada hutan produksi - Kementerian } \\
\text { Kehutanan }\end{array}$ & 6,98 \\
\hline 21 & Izin Penyimpanan LPG/LNG - Kementerian Energi dan SDM & 6,95 \\
\hline 22 & Izin Stasiun Radio - Kementerian Komunikasi dan Informatika & 6,91 \\
\hline 23 & Sertifikasi Guru - Kementerian Pendidikan & 6,88 \\
\hline 24 & Restitusi PPN - Kementerian Keuangan & 6,77 \\
\hline 25 & Izin penyalur alat kesehatan - Kementerian Kesehatan & 6,74 \\
\hline 26 & Rawat Jalan - RSCM & 6,7 \\
\hline 27 & Rawat Inap - RSCM & 6,62 \\
\hline 28 & Layanan Fasilitas Pelabuhan - PT. Pelindo II & 6,53 \\
\hline 29 & Layanan Pendirian Balai Latihan Kerja - Kementerian Tenaga Kerja dan Transmigrasi & 6,48 \\
\hline 30 & Izin impor bahan baku - Kementerian Perdagangan & 6,43 \\
\hline 31 & Izin Pendidikan Luar Sekolah - Kementerian Pendidikan Nasional & 6,33 \\
\hline 32 & Layanan Kapal (Jasa Labuh dan Tambat) - PT. Pelindo II & 6,22 \\
\hline 33 & Pembuatan KTKLN - BNP2TKI & 6,05 \\
\hline
\end{tabular}

Sumber: KPK, 2011 (http://www.kpk.go.id/modules/news/article.php?storyid=1645)

pemasukan dan pengeluaran benih pada Kementerian Pertanian yang mendapatkan skor tertinggi sebesar 7,7 disusul oleh Badan Koordinasi Penanaman Modal dalam pelayanan izin usaha tetap (IUT) dengan nilai 7,67.

Sedangkan dalam laporan tentang hal yang sama, KPK juga mengeluarkan daftar indeks integritas daerah terpilih pada tahun 2010. Pada tabel 2 terlihat bahwa skor tertinggi hanya mencapai 5,82 yang diperoleh Jakarta Barat. Sementara itu kota-kota besar seperti Surabaya dan Makassar masing-masing memiliki nilai sebesar 5,52 menempati urutan ke 9 dan 4,7 di posisi ke 20 . 
Tabel 2 Indeks Integritas Daerah

\begin{tabular}{|c|c|c|}
\hline No. & Kota & $\begin{array}{c}\text { Indeks Integritas } \\
\text { Daerah }\end{array}$ \\
\hline 1 & Jakarta Barat & 5,82 \\
\hline 2 & Samarinda & 5,8 \\
\hline 3 & Jakarta Utara & 5,78 \\
\hline 4 & Tanjung Pinang & 5,72 \\
\hline 5 & Serang & 5,66 \\
\hline 6 & Pontianak & 5,59 \\
\hline 7 & Yogyakarta & 5,59 \\
\hline 8 & Bandung & 5,57 \\
\hline 9 & Surabaya & 5,52 \\
\hline 10 & Ambon & 5,4 \\
\hline 11 & Jakarta Pusat & 5,39 \\
\hline 12 & Jakarta Timur & 5,14 \\
\hline 13 & Manado & 5 \\
\hline 14 & Jakarta Selatan & 4,97 \\
\hline 15 & Jayapura & 4,91 \\
\hline 16 & Mataram & 4,89 \\
\hline 17 & Pekanbaru & 4,89 \\
\hline 18 & Palembang & 4,83 \\
\hline 19 & Semarang & 4,73 \\
\hline 20 & Makassar & 4,72 \\
\hline 21 & Bandar Lampung & 4,54 \\
\hline 22 & Medan & 4,44 \\
\hline
\end{tabular}

Sumber: KPK, 2011 (http://www.kpk.go.id/modules/ news/article.php?storyid=1645)

Hal ini tidak lepas dari sejarah panjang perjalanan birokrasi di negeri ini. Birokrat telah berkembang sebagai penguasa dan bukan sebagai pelayan publik. Implikasinya semakin menyulitkan peningkatan kualitas pelayanan. Paradigma usanginijuga tercermin dari perilaku sebagian besar aparatur negara kita, dimana kepentingan kelompok menjadi tujuan utama daripada menjalankan fungsi utama sebagai abdi masyarakat.
Buruknya integritas pelayanan publik baik di pusat maupun daerah terindikasi karena persoalan sikap dan perilaku koruptif. Struktur dan sistem politik yang korup telah melahirkan apatisme dan sikap yang cenderung toleran terhadap perilaku korupsi. Akibatnya sistem sosial yang terbentuk dalam masyarakat telah melahirkan sikap dan perilaku yang permisif dan menganggap korupsi sebagai suatu hal yang wajar dan normal.

Fenomena inisesuai dengan pernyataan Daniel Lev (2007) bahwa: ${ }^{5}$
"Semua lembaga pemerintahan di tingkat nasional dan lokal telah diperlemah secara fungsional selama masa Orde Baru. Hal ini bukanlah sekadar praktik korup, tetapi-dan secara lebih mendalam lagi-merupakan masalah etos, sebuah re-orientasi yang menjauh dari tanggung jawab sebagaimana didefinisikan secara legal (terutama terhadap publik) dan mendekat kepada kemudahan, pemberian dan kesempatan yang berasal dari cantolan ke kekuasaan politik

Begitu juga pemikiran Thoha (2003) dimana struktur birokrasi, norma, nilai, dan regulasi yang ada dalam birokrasi Indonesia memang masih berorientasi pada pemenuh-an kepentingan penguasa daripada pemenuhan hak sipil warga negara. ${ }^{6}$ Kegagalan pemerintah ini memunculkan sikap apatis dari pengguna layanan, dalam hal ini masyarakat, karena kebutuhan dan aspirasinya tidak dapat diakomodasi.

Daniel Lev , The State and Law Reform in Indonesia, dalam Tim Lindsey, ed., Law Reform in Developing and Transition States, (London: Routledge. 2007).

Eko Prasojo, Op. Cit, hal. 50. 


\section{$\mathrm{R}^{\text {juknal }}$ ECHSVINDING}

Outcome kualitas dan kinerja pelayanan publik juga dirasakan masih jauh dari harapan masyarakat.

Realitas ini tidak bisa dibiarkan begitu saja karena akan berkembang menggurita dalam sikap mental bangsa Indonesia. Penulis menawarkan strategi kerjasama segitiga mewujudkan birokrasi yang professional, efisien, cepat, dan bekerja berdasarkan prinsip-prinsip tata kelola yang baik (good governance).

Memperhatikan kompleksitas permasalahan yang timbul, berikut adalah kerangka kerja yang dapat digunakan dalam mewujudkan transparansi pelayanan publik. Kerangka kerja ini visualisasi dan modifikasi dari tulisan Eigen tentang peran masyarakat madani. $^{7}$

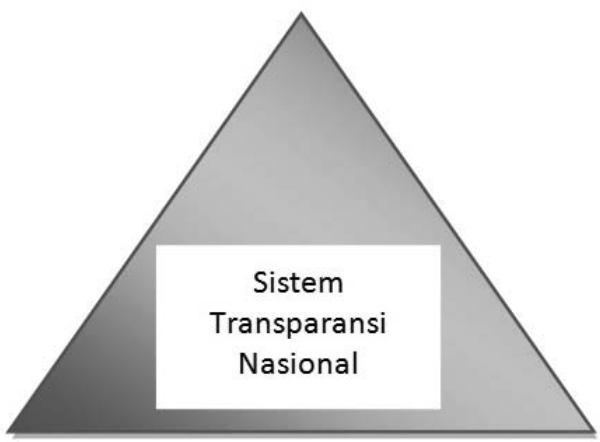

Swasta/Dunia Usaha

Masyarakat

Kerangka kerja segitiga ini terdiri dari tiga pilar yaitu pemerintah, swasta / dunia usaha dan masyarakat. Ketiganya tidak bisa berdiri sendiri melainkan saling berkaitan dan mendukung perwujudan sistem transparansi nasional. Pemerintah berada di puncak segitiga karena memiliki legitimasi yang otoritatif yang diperoleh dari warganya dalam menyelenggarakan jalannya roda pemerintahan (dalam hal ini disamakan pengertian antara pemerintahan dan negara). Dengan demikian, pemerintah juga memiliki kekuatan memaksa yang sah secara hukum untuk diterapkan kepada warganya dalam konteks penyelenggaraan pemerintahan. $\mathrm{Hal}$ ini berupa pelayanan publik yang dilakukan oleh para pejabat publik atau birokrasi.

Sedangkan dua pilar penyangga berikutnya adalah swasta dan masyarakat. Kedudukan swasta atau dunia usaha penting karena menyediakan kebutuhan pemerintah dan masyarakat dalam hal menggerakkan perekonomian melalui mekanisme pasar. Swasta memiliki hubungan yang sangat dekat dengan pemerintah. Bahkan demi memperlancar kepentingan bisnisnya, swasta hampir selalu mengiyakan apa yang dikatakan atau diminta oleh pemerintah. Disinilah potensi pelanggaran prinsip-prinsip good governance bisa terjadi.

Pilar penyangga berikutnya adalah masyarakat, dalam hal ini masyarakat madani. Pemerintah dapat berdiri tegak karena mendapat legitimasi dari masyarakat yang memilihnya. Apalagi dalam sistem demokrasi, pemerintah harus mempertanggungjawabkan semua kebijakan dan tindakannya kepada masyarakatnya. Pemerintah ada untuk melayani masyarakat.

Peter Eigen, "The Role of Civil Society", dalam Corruption and Integrity Improvement Initiatives in Developing Countries, hal. 83-89, diakses dari http://www.undp.org/ governance/contactcdrom_contents/CONTACT.doc/ corruption_report/chapter05.pdf 
Apabila sebaliknya yang terjadi maka masyarakat harus melakukan kontrol dan selanjutnya koreksi atas kebijakan atau tindakan tersebut.

Kerangka kerja segitiga antara pemerintah, swasta dan masyarakat ini tidak bisa berdiri sendiri. Untuk mewujudkan sistem transparansi nasional mereka harus saling bekerja sama mengingat secara alamiah hakekat masing-masing adalah berbeda sehingga saling melengkapi. Pemerintah menyediakan kepemimpinan politik sedangkan swasta berlaku sebagai mesin penggerak perekonomian. Masyarakat madani hadir dan menjadi penggerak bila pemerintah dan atau swasta tidak mampu mencapai hasil yang seharusnya dicapai secara sah atau dengan kata lain melahirkan penyimpangan yang harus dikoreksi.

\section{Peran Civil Society dan Dunia Usaha}

\section{a. Posisi Peran Civil Society}

Implementasi konsep Trias politika bangsa kita semakin luntur kredibilitasnya. Kondisi ini memberikan ruang sekaligus peluang bagi civil society untuk menjadi bagian penting dalam pelayanan publik. Faktor pengawasan memang ranah yang paling memungkinkan untuk organisasi masyarakat dalam mengawal sekaligus menjadi penyeimbang penyelenggaraan kebijakan publik.

Apalagi, Sistem Administrasi Indonesia belum memberikan ruang yang formal bagi masuknya civil society ketika negara memberikan pelayanan kepada rakyatnya. Legitimasi tunggal masih melekat kepada birokrasi sebagai kepanjangan kebijakan politik yang dikonversi menjadi pelayanan publik sebagai salah satu wujudnya. Ruang pengawasan pun saat ini seolah berada dalam ruang yang hampa karena dalam proses artikulasinya kepada pemangku kebijakan, seringkali tidak ditanggapi dan hanya bersifat seremonial semata.

Selain itu, peranan masyarakat madani tidak lagi sekedar pengawasan dari luar sebagai alternatif dari fungsi pengawasan internal birokrasi yang ada. Melainkan, masyarakat madani dapat sekaligus melakukan penguatan peran kelembagaan lainnya. Oleh karena itu penguatan peran masyarakat sipil ini penting karena posisinya sebagai stakeholders sekaligus penerima manfaat pelayanan.

Terdapat beberapa padangan tentang peran masyarakat madani sebagai satu pilar penopang kerangka kerja segitiga yang dapat dilakukan dalam mendorong terwujudkan sistem transparansi nasional. Pertama, peran civil society dalam monitoring penyelenggaraan pelayanan publik selama ini meliputi advokasi dan pengawasan yang teridentifikasi dalam bentuk katalisator dialog (catalyst of dialogue), melakukan penyeimbang kepentingan (balancing interest), pemberian sinyal (picking up signals), dan mobilisasi untuk aksi bersama. ${ }^{8}$ 
Identifikasi peran-peran tersebut apabila diperhatikan dalam dinamika masyarakat memang mulai menguat dalam agenda pemberantasan sikap dan perilaku korupsi. Peran civil society sebagai katalis dilakukan dengan instrumen dialog antara pembuat kebijakan, pemberi layanan dan masyarakat sebagai subjek sekaligus objek kebijakan. Dialog ini biasanya dilakukan untuk mencapai konsensus atau kesepakatan bersama antara pemerintah, masyarakat dan stakeholders lainnya untuk memformulasikan dan membuat role model penyelenggaraan kebijakan.

Lokus peran civil society dalam meminimalisir perilaku permisif sekarang ini tidak lagi berkutat pada tataran hilir semata. Penguatan peran di tataran hulu juga tampak, dalam rangka memperbaiki paradigma para pemangku kebijakan untuk menjalankan tugas dan tanggung jawabnya sebagai abdi negara.

Hal tersebut berkait dengan peran yang kedua. Penguatan peran civil society dalam melakukan sosialisasi dan konsultasi. Penguatan ini difokuskan dalam membangun kerangka hukum dan kebijakan publik. Bentuk advokasi yang dilakukan antara lain dengan memperjuangkan aspirasi dan kepentingan publik saat formulasi kebijakan publik dalam bentuk undang-undang, peraturan pemerintah pusat dan daerah (Perda) dilaksanakan.

Dalam konteks ini, masyarakat madani berperan sebagai sumber keahlian dan pengetahuan yang spesifik dan independen bagi birokrasi. Dengan atribut yang dimiliki berbagai organisasi masyarakat ini, mereka dapatmemberikan asistensi, nasehat-nasehat yang profesional kepada pejabat publik atas sesuatu hal (baca: kebijakan publik dan atau rancangannya).

Peran sosialisasi tersebut diatas juga meliputi pemberian penjelasan atas keuntungan dan manfaat suatu rancangan atau kebijakan publik baik kepada masyarakat luas maupun pejabat publik itu sendiri. Peran ini dapat dilakukan dalam bentuk kampanye publik (public campaign) membangun kesadaran masyarakat dan juga aparat pemerintah. Sedangkan dari sisi konsultasi, civil society menerapkan peran sebagai katalisator proses berbagi pengetahuan (knowledge sharing) hingga melakukan pelatihan-pelatihan.

Peran civil society yang ketiga adalah menjadi sumber ide-ide/gagasan pemikiran baru yang inovatif demi perbaikan pelayanan publik. Ide inovatif ini dapat digali dari kekayaan pengetahuan lokal (indigenous knowledge) maupun berasal dari pengalaman keberhasilan dari negara lain. Masyarakat madani dapat melakukan riset tentang pengalaman terbaik di berbagai negara tentang suatu hal (misal, pemberantasan korupsi) yang kemudian disesuaikan dengan konteks lokal ke-Indonesiaan. Misalnya, lahirnya produk undang-undang diantaranya UU No. 30 Tahun 2002 tentang Komisi Pemberantasan Tindak Pidana Korupsi.

Contoh lain sosialiasi dan kampanye publik yang dilakukan masyarakat madani adalah adanya dukungan yang besar terhadap diskriminasi perlakuan hukum terhadap rakyat kecil yang 
kerap terjadi akhir-akhir ini seperti kasus Aguswandi pengecas handphone, kasus Prita melawan RS Internasional Omni Tangerang hingga memunculkan solidaritas massa berupa penggalangan "koin keadilan untuk Prita", sampai Kasus seorang nenek Minah melawan PT RSA di Banyumas yang didakwa mencuri tiga biji kokoa dan lain-lain. Hal ini menunjukkan semakin tingginya kesadaran masyarakat terhadap peran mereka dalam mewujudkan transparansi dalam pelayanan publik. Kemampuan melakukan pengawasan atas jalannya kebijakan atau proses penegakan hukum tersebut merupakan wujud peran keempat dari civil society.

Terakhir, civil society juga berperan dalam memberikan pendidikan terhadap masyarakat luas. Pendidikan dirasa penting untuk menumbuhkembangkan semangat antikorupsi dengan mengedepankan transparansi mengingat pola perilaku korupsi tidak akan bisa ditumbangkan dengan ancangan parsial. Penumbangan pola perilaku korupsi meniscayakan ancangan holistik yang ditandai perubahan seluruh wilayah kepribadian, baik wilayah kognitif (pengetahuan), afektif (sikap dan kemauan), dan behavioral (tindakan). Dalam kesempatan yang sama, sangat diperlukan juga pengkondisian lingkungan sosial yang bersifat menolak, menentang, serta menghukum korupsi di satu sisi, tetapi juga menerima, mendukung, dan menghargai sikap antikorupsi. Peran masyarakat sipil, utamanya LSM, menjadi penting sebagai salah satu subyek pengkondisian itu. Di sinilah esensi peran yang kelima berupa membangun kapasitas (capacity building) terutama bagi warga negara.

\section{b. Peran Dunia Usaha: Dua Sisi Mata Uang}

Berdasarkan kerangka kerja segitiga di atas, peran swasta merupakan penggerak dari dinamika perekonomian suatu bangsa. Dunia usaha menjadi pilar yang strategis karena memiliki dua peran tak terpisahkan bak dua sisi mata uang. Pertama, dunia usaha potensial berkontribusi pada berjalannya sistem pelayanan publik yang profesional, cepat, efisien, dan berbiaya rendah. Yakni dengan mendorong birokrasi untuk melakukan praktek-praktek pelayanan publik berdasarkan prinsip good governance dalam sistem pelayanan publik yang baik.

Dunia usaha tidak mentolerir atau tidak memberikan uang sogok, tidak memberikan hadiah atau iming-iming barang, uang, dan atau jasa tertentu bagi para pelayan pelayanan publik dalammelayanikepentingan dunia usaha. Yang harus ditunjukkan oleh dunia usaha adalah bagaimana mendapat pelayanan terbaik, cepat, dengan biaya yang jelas dan pasti setelah memenuhi persyaratan yang diperlukan.

Dunia usaha harus cerewet dalam arti kritis dengan mendorong pemerintah untuk membangun sistem pelayanan publik yang baik. Dengan kata lain, dunia usaha dapat berpartisipasi mewujudkan sistem transparansi nasional bila ia tidak memberikan imbalan tertentu bagi para birokrat dalam menjalankan tugasnya. Bila ini tercapai maka dunia usaha berperan positif dalam menggerakkan perekonomian bangsa dengan cara-cara berbisnis yang 
berlandaskan etika dan prinsip tata kelola yang baik.

Peran kedua adalah, dunia usaha berpotensi dapat menghambat terwujudnya sistem transparansi nasional. Bahkan berpotensi pula menghancurkan sistem pelayanan publik yang sudah ada, yang semestinya ditingkatkan, bila dunia usaha melakukan tindakan-tindakan yang melawan etika dan melanggarkan prinsip good governance. Misalnya, karena ingin cepat mendapatkan izin maka dunia usaha memberikan iming-iming hadiah tertentu kepada oknum birokrat. Masih banyak contoh lain seperti kenginan mendapatkan keringanan hukuman, keinginan menang dalam tender pemerintah dan keinginan mendapatkan dispensasi atas syarat-syarat tertentu dan lain-lain.

Dalam tulisan ini akan dipaparkan salah satu hasil penelitian yang penulis dan tim lakukan tentang best practice pelayanan usaha di tiga kota di Indonesia pada era otonomi daerah'. Dalam penelitian ini melibatkan peran masyarakat dan dunia usaha dalam pelayanan publik khususnya perizinan usaha di Purbalingga, Makassar dan Banjarbaru.

Dari temuan, paparan dan analisa dalam penelitian yang dilakukan kemudian diabstraksikan ke dalam sebuah model best practice perijinan usaha yang integratif sepertigambar di atas. Model ini menjelaskan bagaimana best practice perijinan usaha suatu daerah dapat terbangun di era otonomi daerah yang memiliki berbagai permasalahan dan harus menghadapi tantangan yang kompleks. Model ini terdiri dari tiga komponen utama yaitu komponen modal masyarakat dan karakteristik daerah, komponen modal pemerintahan (governance dalam arti luas) dan komponen model pemerintah pusat. Komponen pertama adalah modal masyarakat dan karakteristik daerah. Letaknya ada di bagian paling bawah model tersebut. Komponen ini berupa modal, kapasitas, kapabilitas, karakteristik khas yang dimiliki daerah tersebut dan melekat pada masyarakat setempat.

Hal ini dapat digambarkan dengan diagram berikut ini yang di dalamnya terbagibagi menjadi enam sub komponen:

a. Ketersediaan dan kualitas tenaga kerja, adanya modal finansial dan sumber daya alam yang dimiliki daerah tersebut.

b. Bahan baku yang tersedia dan sejauh mana proses produksi bisa berjalan dengan baik dalam mendukung rantai produksi perusahaan sehingga menciptakan nilai tambah (value added).

c. Kearifan lokal (local wisdom), budaya perusahaan dan semangat kewirausahaan para pelaku usaha di daerah tersebut.

d. Tentu tidak kalah pentingnya adalah terjaganya ketertiban, keamanan dan cita rasa keramahan masyarakat.

Tirta N. Mursitama, Hamid Chalid, Desy Hariyati dan Sigit Indra Prianto, Reformasi Pelayanan Perizinan dan Pembangunan Daerah: Cerita Sukses Tiga Kota (Purbalingga, Makassar, Banjarbaru), (Jakarta: Masyarakat Transparansi Indonesia, 2010). 


\section{$\mathrm{R}_{\mathrm{ECE}}^{\text {duknal HTSVINDING }}$}

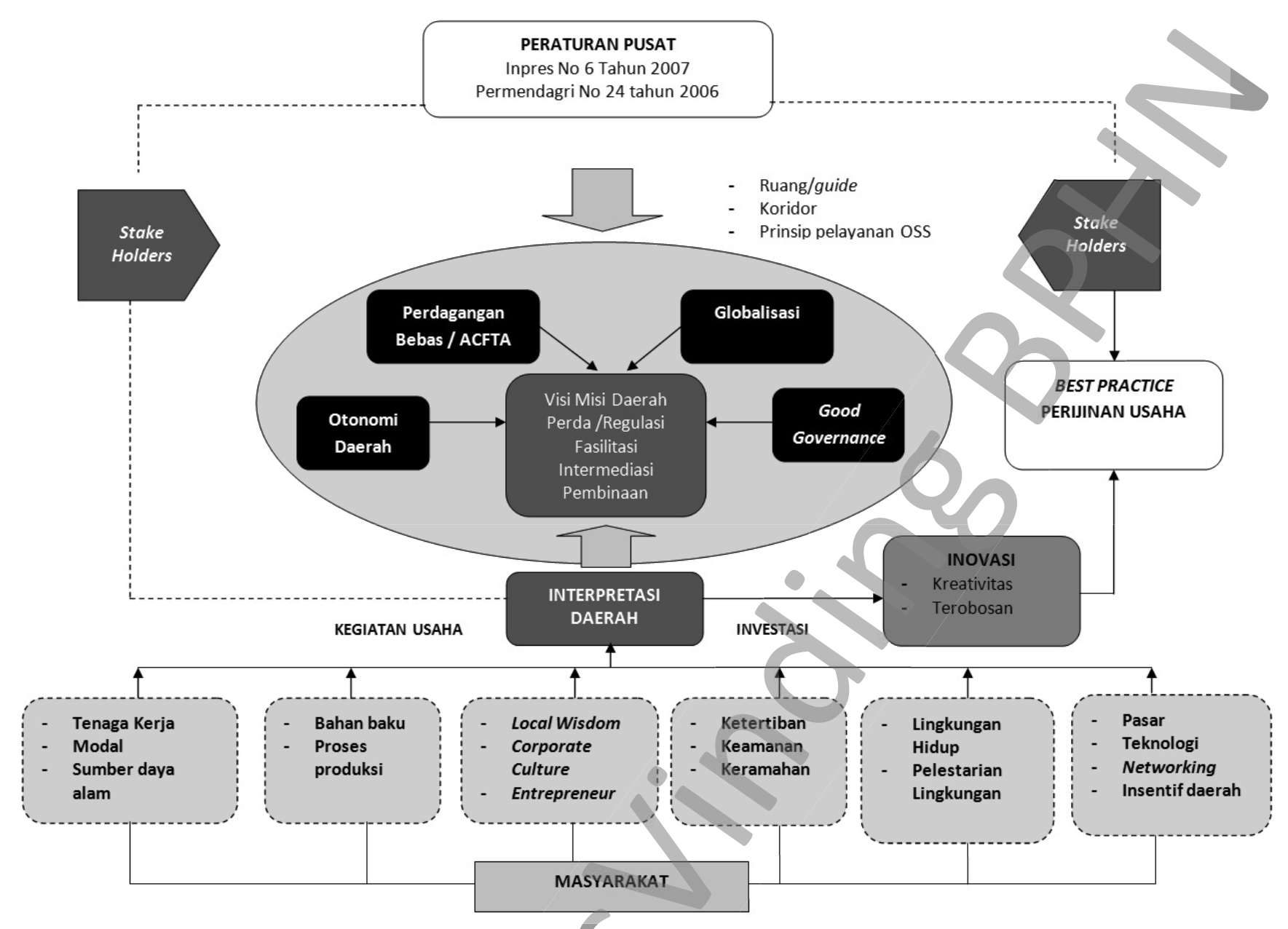

e. Komitmen dan kepedulian terhadap lingkungan hidup sehingga setiapaktifitas bermasyarakat, bekerja, berproduksi dalam perusahaan maupuan dalam sektor lain pun harus memperhatikan pelestarian lingkungan. Lebih dalam lagi, bagaimana mampu mewujudkan ekologi hijau (green ecology).

f. Seberapa besar pasar yang ada di wilayah tersebut, kemampuan teknologi yang dimiliki para pelaku usaha.

Komponen kedua adalah modal pemerintahan (governance dalam arti luas). Dalam komponen kedua yang terpenting adalah bagaimana visi dan misi daerah dapat disusun dengan mempertimbangkan intepretasi atas modal pemerintah pusat berupa peraturan-peraturan pemerintah pusat dan intepretasi atas modal masyarakat dan karakteristik kedaerahan yang dimiliki oleh daerah tersebut. Dua arus intepretasi besar ini sangat dinamis. Disatu sisi peraturanperaturan pusat kadang secara substansi terlalu umum atau melakukan generalisasi untuk seluruh wilayah Indonesia. Belum lagi seringnya aturan pusat itu berganti ketika implementasi di daerah belum berjalan dengan sempurna akibatnya minimnya sosialiasi. Hal ini semakin rumit bila peraturan tersebut merupakan produk pertarungan kepentingan-kepentingan tertentu demi meraih kekuasaan atau melanggengkannya. 


\section{$\mathrm{R}^{\text {juknal }}$ ECHSVINDING}

Sedangkan di sisi yang lain, kemampuan intepretasi pemerintah daerah atas modal masyarakat dan karakteristik wilayah juga tidak kalah penting. Diperlukan kejelian melihat, menganalisis dan akhirnya mengejawantahkan modal tersebut ke dalam bentuk visi dan misi daerah. Jadi, visi dan misi daerah merupakan produk akhir dari tarikan-tarikan intepretasi atas peraturan pemerintah pusat dan modal masyarakat dan karakteristik daerah. Hasil akhir visi dan misi daerah tidak bisa serta merta dikatakan sebagai intepretasi yang lebih berat dari salah satu sisi saja, misalnya apakah intepretasi atas peraturan-peraturan pemerintah (central government heavy) atau intepretasi atas masyarakat dan karakteristik daerah (local heavy). Tentu, seberapa besar komposisi di antara keduanya, hanya diketahui dan dipahami oleh pemerintahan daerah dengan segenap pranata politik, pelaku usaha dan masyarakat di daerah tersebut.

Ternyata intepretasi atas dua komponen tersebut tidaklah cukup karena dalam penyusunan visi dan misi daerah faktor yang mempengaruhi sangat kompleks. Merujuk pada model di atas, di dalam lingkaran penyusunan visi dan misi daerah dipengaruhi juga oleh sub elemen lain yaitu:

a. kekuatan dan pengaruh globalisasi yang paling tidak akan menimbulkan tuntutan pembebasan tarif atau penurunan tarif hingga seminim mungkin, terjadi arus masuk dan keluar barang (free flow of goods) dan jasa (free flow of services) hingga sumber daya manusia (free of natural person/skilled-labor); b. adanya perdagangan bebas hingga secara spesifik ditandatanganinya perjanjian bebas antara ASEAN dan China (ASEAN China Free Trade Agreement). Daerah harus lebih lihai menyiasati agar mendapatkan berkah positif dari perdagangan bebas dan ACFTA ini. Walaupun untuk hal terakhir, Indonesia dalam posisi yang lemah dan dirugikan. Artinya keuntungan yang kita dapatkan jauh lebih kecil dibandingkan yang China dapatkan;

c. otonomi daerah (power shifting from central to local government) dan pemberian wewenang yang lebih besar kepada daerah sebenarnya bisa menjadi peluang. Daerah bisa mengejawantahkan pemikiran-pemikiran mereka sendiri dan akhirnya mengimplementasikannya tentu setelah ditetapkan dana visi dan misi daerah;

d. tata kelola pemerintahan yang baik (good governance) berperan penting untuk mengatur tata hubungan antar lembaga sesuai dengan tugas pokok dan fungsinya, mengatur agar tidak ada penyalahgunaan wewenang (abuse of power) di antara para aktor yang terlibat. Dengan demikian, ide-ide tersebut dapat disusun tidak hanya secara sistematis dan secara substantif memenuhi syarat, tetapi juga secara prosedural dan mekanismenya pun jelas. Akhirnya, dengan adanya tata kelola yang baik ini menjamin adanya transparansi, akuntabilitas, responsibilitas, keadilan 
dan independensi di dalam proses pemerintahan daerah.

Dari modal pemerintahan (governance dalam arti luas) lahirlah suatu kreatifitas, terobosan-terobosan berupa inovasi yang bertujuan meningkatkan pembangunan daerah. Tidak lain tidak bukan inovasi ini lahir dari proses di dalam modal pemerintahan setelah mempertimbangkan dinamika intepretasi modal pemerintah pusat dan modal daerah dalam bentuk investasi. Untuk dapat melahirkan inovasi harus melalukan serangkaian investasi. Ada yang beresiko tinggi dengan imbal yang tinggi (high risk, high return) atau investasi dengan resiko sedang atau rendah dengan imbal yang tentu tidak setinggi investasi lainnya.

Serangkaian investasi, dalam konteks ini adalah dalam bidang usaha ekonomi bertujuan untuk mendorong penanaman modal yang lebih tinggi lagi baik secara domestik (dari daerah itu, maupun dari luar daerah tersebut) hingga penanaman modal asing dari luar negeri. Inovasi yang terusmenerus, kadang gagal tapi tak sedikit yang berhasil, akhirnya melahirkan best practice dalam perijinan usaha (cerita sukses dalam reformasi perijinan usaha).

$\mathrm{Hal}$ terakhir yang tidak bisa ditinggalkan adalah, langkah yang dilakukan pelaku pemerintahan, pelaku usaha di daerah (dalam modal pemerintahan) itu harus pula mempertimbangkan atau ditujukan untuk kepentingan stakeholders yang luas. Pemangku kepentingan ini pada intinya adalah publik, bukan individu-individu atau elit-elit tertentu. Dengan demikian fungsi kontrol juga akan berjalan. Yakni, apakah produk dari modal pemerintahan tadi selaras dengan apa yang dicitakan/diharapkan publik. Bila tidak, bisa dipastikan investasiinvestasi yang dilakukan tidak akan berhasil dan tidak akan menjadi cerita-cerita sukses reformasi perijinan usaha.

\section{G. Penutup}

\section{Kesimpulan}

Dari uraian di atas, dapat dirumuskan beberapa kesimpulan sebagai berikut:

a. Dalam pelayanan publik, terdapat 3 (tiga) aktor yang terlibat, yaitu: masyarakat, dunia usaha, dan pemerintah yang dimotori oleh birokrasi. Ketiganya tidak bisa berdiri sendiri melainkan saling berkaitan dan mendukung perwujudan sistem transparansi nasional. Pemerintah memiliki peran sangat penting karena memiliki legitimasi yang otoritatif yang diperoleh dari warganya dalam menyelenggarakan jalannya roda pemerintahan. Dengan demikian, pemerintah juga memiliki kekuatan memaksa yang sah secara hukum untuk diterapkan kepada warganya dalam konteks penyelenggaraan pemerintahan. Hal ini berupa pelayanan publik yang dilakukan oleh para pejabat publik atau birokrasi. Kedudukan swasta atau dunia usaha juga penting karena menyediakan kebutuhan pemerintah dan masyarakat dalam hal menggerakkan perekonomian melalui 


\section{$\mathrm{R}^{\text {juknal }}$ ECHSVINDING}

mekanisme pasar. Swasta memiliki hubungan yang sangat dekat dengan pemerintah. Bahkan demi memperlancar kepentingan bisnisnya, swasta hampir selalu mengiyakan apa yang dikatakan atau diminta oleh pemerintah. Di sinilah potensi pelanggaran prinsipprinsip good governance bisa terjadi. Pilar penyangga berikutnya adalah masyarakat, dalam hal ini masyarakat madani. Pemerintah dapat berdiri tegak karena mendapat legitimasi dari masyarakat yang memilihnya. Apalagi dalam sistem demokrasi, pemerintah harus mempertanggungjawab-kan semua kebijakan dan tindakannya kepada masyarakatnya. Pemerintah ada untuk melayani masyarakat. Apabila sebaliknya yang terjadi maka masyarakat harus melakukan kontrol dan selanjutnya koreksi atas kebijakan atau tindakan tersebut.

b. Menurut survei yang dilaksanakan oleh KPK, integritas pelayanan publik baik di pusat maupun di daerah terus mengalami penurunan. Padatahun 2008, indeks pelayanan publik di tingkat pusat adalah 6,84 kemudian menurun menjadi 6,64 pada tahun 2009. Pada tahun 2010 kembali mengalami penurunan ke angka 6,16 . Walau masih di atas angka 6 yang merupakan standar minimal pelayanan publik yang dianggap memadai. Ini menandakan ada permasalahan dalam pelayanan publik. Bahkan untuk pelayanan publik di daerah di bawah standar minimum yang ditetapkan KPK. Buruknya integritas pelayanan publik baik di pusat maupun daerah terindikasi karena persoalan sikap dan perilaku koruptif. Struktur dan sistem politik yang korup telah melahirkan apatisme dan sikap yang cenderung toleran terhadap perilaku korupsi. Akibatnya sistem sosial yang terbentuk dalam masyarakat telah melahirkan sikap dan perilaku yang permisif dan menganggap korupsi sebagai suatu hal yang wajar dan normal.

c. Implementasi konsep Trias politika bangsa kita semakin luntur kredibilitasnya. Kondisi ini memberikan ruang sekaligus peluang bagi civil society dan dunia usaha untuk menjadi bagian penting dalam pelayanan publik, peran ini dapat digambarkan sebagai berikut:

\section{1) Peran Masyarakat Madani:}

a) Masyarakat dapat menjalankan peran pengawasan. Faktor pengawasan memang ranah yang paling memungkinkan untuk organisasi masyarakat dalam mengawal sekaligus menjadi penyeimbang penyelenggaraan kebijakan publik. Selain itu, peranan masyarakat madani dapat sekaligus melakukan penguatan peran kelembagaan lainnya. Oleh karena itu penguatan peran masyarakat sipil ini penting karena posisinya sebagai 
stakeholders sekaligus penerima

manfaat pelayanan.

b) Masyarakat madani juga berperan sebagai sumber keahlian dan pengetahuan yang spesifik dan independen bagi birokrasi. Dengan atribut yang dimiliki berbagai organisasi masyarakat ini, mereka dapat memberikan asistensi, nasehatnasehat yang profesional kepada pejabat publik atas sesuatu hal (baca: kebijakan publik dan atau rancangannya).

c) Masyarakat madani dapat menjadi menjadi sumber ideide/gagasan pemikiran baru yang inovatif demi perbaikan pelayanan publik. Ide inovatif ini dapat digali dari kekayaan pengetahuan lokal (indigenous knowledge) maupun berasal dari pengalaman keberhasilan dari negara lain. Masyarakat madani dapat melakukan riset tentang pengalaman terbaik di berbagai negara tentang suatu hal (misal, pemberantasan korupsi) yang kemudian disesuaikan dengan konteks lokal ke-Indonesiaan. Misalnya, lahirnya produk undang-undang diantaranya UU No. 30 Tahun 2002 tentang Komisi Pemberantasan Tindak Pidana Korupsi. d) Masyarakat madani dapat memberikan pendidikan terhadap masyarakat luas. Pendidikan dirasa penting untuk menumbuhkembangkan semangat antikorupsi dengan mengedepankan transparansi mengingat pola perilaku korupsi tidak akan bisa ditumbangkan dengan ancangan parsial. Penumbangan pola perilaku korupsi meniscayakan ancangan holistik yang ditandai perubahan seluruhwilayahkepribadian, baik wilayah kognitif (pengetahuan), afektif (sikap dan kemauan), dan behavioral (tindakan). Dalam kesempatan yang sama, sangat diperlukan juga pengkondisian lingkungan sosial yang bersifat menolak, menentang, serta menghukum korupsi di satu sisi, tetapi juga menerima, mendukung, dan menghargai sikap antikorupsi. Peran masyarakat sipil, utamanya LSM, menjadi penting sebagai salah satu subyek pengkondisian itu. Disinilah esensi peran yang kelima berupa membangun kapasitas (capacity building) terutama bagi warga negara.

\section{2) Peran Dunia Usaha:}

a) Dunia usaha potensial berkontribusi pada berjalannya sistem pelayanan publik yang 


\section{$\mathrm{R}^{\text {juenal }}$ ETSVINDING}

profesional, cepat, efisien, dan berbiaya rendah. Yakni dengan mendorong birokrasi untuk melakukan praktek-praktek pelayanan publik berdasarkan prinsip good governance dalam sistem pelayanan publik yang baik. Dunia usaha harus menunjukkan bagaimana mendapat pelayanan terbaik, cepat, dengan biaya yang jelas dan pasti setelah memenuhi persyaratan yang diperlukan.

b) Dunia usaha dapat pula berpotensi menghambat terwujudnya sistem transparansi nasional. Bahkan berpotensi pula menghancurkan sistem pelayanan publik yang sudah ada, yang semestinya ditingkatkan, bila dunia usaha melakukan tindakan-tindakan yang melawan etika dan melanggarkan prinsip good governance. Misalnya, karena ingin cepat mendapatkan izin maka dunia usaha memberikan iming-iming hadiah tertentu kepada oknum birokrat. Masih banyak contoh lain seperti kenginan mendapatkan keringanan hukuman, keinginan menang dalam tender pemerintah dan keinginan mendapatkan dispensasi atas syarat-syarat tertentu dan lain-lain.

\section{Saran}

Dari uraian di atas, dapat dirumuskan beberapa saran sebagai berikut:

a. Perlu dibangun strategi kerjasama segitiga antara pemerintah, masyarakat dan dunia usaha dalam rangka mewujudkan birokrasi yang professional, efisien, cepat, dan bekerja berdasarkan prinsipprinsip tata kelola yang baik (good governance).

b. Perlu penguatan peran masyarakat sipil. Hal ini penting karena posisinya sebagai stakeholders sekaligus penerima manfaat pelayanan.

c. Dunia Usaha perlu lebih kritis dengan mendorong pemerintah untuk membangun sistem pelayanan publik yang baik. Dengan kata lain, dunia usaha dapat berpartisipasi mewujudkan sistem transparansi nasional bila ia tidak memberikan imbalan tertentu bagi para birokrat dalam menjalankan tugasnya. Bila ini tercapai maka dunia usaha berperan positif dalam menggerakkan perekonomian bangsa dengan cara-cara berbisnis yang berlandaskan etika dan prinsip tata kelola yang baik. 


\section{DAFTAR PUSTAKA}

Antlov, Hans, Rustam Ibrahim dan Peter van Tuij, NGO Governance and Accountability in Indonesia:

Challenges in a Newly Democratizing Country dalam Lisa Jordan dan Peter van Tuij (eds), NGO Accountability: Politics, Principles and Innovations, (London: Earthscan, 2006).

Eigen, Peter, The Role of Civil Society", dalam Corruption and Integrity Improvement Initiatives in Developing Countries, http://www.undp.org/governance/ contactcdrom_contents/ CONTACT. doc/ corruption_report/chapter05.pdf.

Lev, Daniel, The State and Law Reform in Indonesia, dalam Tim Lindsey, ed., Law Reform in Developing and Transition States, (London: Routledge, 2007).

Malik, Abdul, Studi peran civil society dalam monitoring kegiatan Operasi Pasar Khusus (OPK) beras di Kelurahan Galur Kecamatan Johar Baru Jakarta Pusat, Siregar, http://www.digilib.ui.ac.id/.

Mursitama, Tirta N., Hamid Chalid, Desy Hariyati dan Sigit Indra Prianto, Reformasi Pelayanan Perizinan dan Pembangunan Daerah: Cerita Sukses Tiga Kota (Purbalingga, Makassar, Banjarbaru), (Jakarta: Masyarakat Transparansi Indonesia, 2010).

Prasodjo, Eko, Reformasi Kedua, (Jakarta: Salemba Humanika, 2009).

Soekanto, Soerjono dan Sri Mamudji, Penelitian Hukum Normati: Suatu Tinjauan Singkat, (Jakarta: CV. Rajawali, 2011). 